\title{
EVALUATION OF ALOE VERA L. AS PHYTOREMEDIATOR OF HEAVY METALS CONTAMINATED SOILS IN ARID ENVIRONMENTS
}

\author{
ElHaG, M. ${ }^{1 *}-$ AL-GHAmDI, A. A. M. ${ }^{2}-$ GALAL, H. K. ${ }^{2}$ - DAHLAN, A. ${ }^{2}$ \\ ${ }^{I}$ Department of Hydrology and Water Resources Management, Meteorology, Environment and \\ Arid Land Agriculture, King Abdulaziz University, 21589 Jeddah, Saudi Arabia \\ ${ }^{2}$ Department of Botany, Environment Program, Faculty of Biological Science, King Abdulaziz \\ University, P.O. Box 35009, Jeddah 21488, Saudi Arabia \\ *Corresponding author \\ e-mail:melhag@kau.edu.sa
}

(Received $5^{\text {th }}$ Jun 2018; accepted $31^{\text {st }}$ Aug 2018)

\begin{abstract}
Decontamination of heavy metal polluted soil and water by plants is called phytoremediation. Succulent plant species such as Aloe vera (L.) are considered for the current study to investigate their ability to accumulate heavy metals and their uptake rate of different heavy metals are tested. This study aimed to measure the concentration of toxic heavy metals ( $\mathrm{As}, \mathrm{Cd}, \mathrm{Cr}, \mathrm{Cu}, \mathrm{Pb}, \mathrm{Hg}$, and $\mathrm{Ni}$ ) in arid contaminated soils of Saudi Arabia. The soil was contaminated with $1500 \mathrm{ppm}$ of each element. During a year of the experiment, 4 samples were taken on a trimester basis. All samples were digested to measure heavy metal content in soil and plant. Metal Transfer Factor (MTF) and Translocation Factor (TF) were calculated from the examined data. This study showed that the A. vera has the ability to decontaminate heavy metals from polluted soil. The greatest accumulation was detected from As but the accumulation was declined after 9 months. $\mathrm{Hg}$ accumulation showed no significant results of heavy metal uptake by $A$. vera. The greatest MTF was of Cd elements and counted for 1.3404 and the lowest was of $\mathrm{Cr}$ and counted for 0.1292. Cd TF was the maximum (2.8538) but $\mathrm{Pb} \mathrm{TF}$ was the minimum (1.2191).
\end{abstract}

Keywords: accumulation ability, metal transfer factor, succulent plant, soil treatment, translocation factor

\section{Introduction}

The medium for plant root growth and waste disposal is the soil. Moreover, it is a transmitter of different contaminants in water, air, and food. Soil pollution has effects on the natural quality of agricultural crops and water resources. Subsequently, it may menace human health and may affect the quality of the atmosphere. Some attention has gone to soil pollution linked to crops in the past (Wong, 1996). Also, the polluted soil affecting the functions of soil and the environment has been gradually confirmed by environmentalist (Tiller, 1992).

Heavy metals are physical constituents of the soil's profile. Human industrial activities, as well as extensive agricultural practices, have hardly changed the stability and biological cycles of many heavy metals (Elhag and Bahrawi, 2016; Elhag et al., 2017a). An assessment of the ecological danger due to the polluted soil is of importance for agricultural zones, because of heavy metals that are potentially harmful to all organisms not only human, persist in soils for many years (Grzebisz et al., 2001).

The riskiest hazards affecting both rich and poor countries are heavy metal pollution. Industrialization, fossil fuel consumption and the production of a variety of chemical compounds has led to the worldwide deterioration of the quality of the environment (Chakravarty et al., 2010). All trace elements at the high level of concentrations have 
intense poisonous effects and are viewed as pollutants of the environment (Rashed and Niyazi, 2017).

Phytoremediation is a sustainable, cost-effective, green technique to decontaminate the environment from pollutants such as heavy metals, insecticides, thinners, explosive material, petroleum, polycyclic aromatic hydrocarbons, and landfill leachate in the soil, water, and sediments. It involves the use of plants to take off, move out, balance and control pollutants in soil and water (Hughes et al., 1996). It is a weak entered approach depending on biological attenuation by biodegradation and physiochemical devices that decrease the concentration of the contaminant (Parrish et al., 2005; Schwab and Banks, 1993).

The implementation of phytoremediation approach in arid regions requires special plant selection and is anticipated to be less feasible than in humid regions with more favorable climate for plant growth. The arid climate considered by low annual rainfall and high wind make the phytoremediation research challenging in the Middle East. For phytoremediation in arid and semiarid areas, it is necessary to set up a varied phytocoenosis, including plants that can accumulate, stabilize or degrade contaminants (Piha et al., 1995). Phytoremediation is very hopeful for the removal of pollutants from the soil and water (Garbisu and Alkorta, 2003).

Phytoremediation of metal contaminants falls within four different phytoremediation strategies, each of which includes several techniques of actions for remediating heavy metal pollution: Phytostabilization is the restraint of pollutants in the soil by plants, through uptake by roots, adsorption onto roots or precipitation within the root of the plant grows under soil and maintain the physical balance of soils (Padmavathiamma and $\mathrm{Li}$, 2007), Phytofiltration means that plants use roots or seedlings to accumulate contaminants, heavy metals, from water and aqueous waste streams (Prasad and Freitas, 2003), During the process of phytovolatilization plants absorb these heavy metals in elemental forms from the polluted soil, and their biologically convert them into gaseous forms that are finally emitted into the air (Thangavel and Subbhuraam, 2004). Phytoextraction is the uptake of heavy metals from the polluted soil by plants and their translocation to harvestable green parts of the plant where they accumulate (Padmavathiamma and Li, 2007).

Phytoremediation can involve grasses, shrubs as well as trees. Grasses can run a groundcover and limit wind dispersion which plants provide a wide canopy and develop a deep network of plant root to prevent soil erosion. (Williams and Twine, 1960). The roots of plants in the soil play a chief role in metal removal by purification, uptake and cation exchange, and plant induced chemical changes in the narrow region of soil (Dunbabin and Bowmer, 1992). A heavy metal will only become toxic if its concentration in the plants exceeds the allowable threshold. Plants have been divided into three groups based on their acceptance to accumulate metals: Excluders are plants insensitive for absorption and accumulation of heavy metals, Indicators are plants that content of heavy metal linearly responds to increasing availability of heavy metals in contaminated soil and Accumulators are plants accumulating higher contents of heavy metals in their tissues per their rise in the soil than others (Peer et al., 2005).

Some plants in the group of accumulators called hyperaccumulators, which it can accumulate 100 times higher levels of a specific heavy metal in their shoot tissues compared with regular, non-accumulator plants (Reeves and Baker, 2000). A hyperaccumulator is a plant that can grow in polluted soil with very high concentrations of heavy metals, and uptake these heavy metals through their roots, and accommodate 
very high levels of metals in their tissues. The ability to hyperaccumulate toxic heavy metals compared to other plant species has been exposed to be due to several gene expressions and regulations of the same genes in different plants. (Ali et al., 2013).

There are 41 species of Aloe recorded from the Arab region which encompass the countries of Saudi Arabia (Newton, 2001), Yemen (including Socotra) and Oman. The aloes are principally restricted to the areas in the west and south-west of the peninsula (Walker, 2005).

The main objective of the current study is to investigate the ability of $A$. vera in phytoremediation practice of soils polluted with heavy metals in Saudi Arabia. Metal Transfer Factor and Translocation Factor are the evaluation criteria which used to conduct the designated research study.

\section{Materials and methods}

\section{Study area description}

The Kingdom of Saudi Arabia is influenced by several natural factors, the most important of which is the Astronomical Observatory. The Kingdom is located between 16 degrees and 33 degrees North and 34 and 56 East longitudes, making it the largest part of the dry tropical desert region in South Asia (Sen et al., 2017). The climate of the Kingdom is characterized by drought throughout the year and by high temperatures especially in the summer (Elhag and Bahrawi, 2014a). The geographic location of Saudi Arabia and its varied geological composition and different surface and climatic features from one region to another led to the existence of many natural environments that differ in the components of the vegetation cover (Elhag et al., 2015) from one place to another. Most of the Kingdom's regions are located in dry areas except the Empty Quarter and the Sarawat Mountains within the semi-arid regions. Much of the Kingdom's soil is calcareous because of insufficient rainfall to wash calcium carbonate. Because of these conditions, the Kingdom's environment is fragile and sensitive (Elhag and Bahrawi, 2014b). Saudi Arabia is located in a geographical area lacking fresh water and has no natural resources such as springs, rivers, and lakes with scarcity or lack of rainfall in some areas. Natural resources in the Kingdom are limited to some wells, rainwater pools, and floods that have not been sufficient to meet the essential needs (Elhag et al., 2017b).

\section{Experimental design}

The experiment was designed in a tinplate tank with dimensions of $100 \times 50 \times 75 \mathrm{~cm}$, length, width, and height, respectively. Four tanks were prepared to implant A. vera juveniles in PittMoss soils. A. vera is a stemless plant growing to $50 \mathrm{Inch}$, spreading by offsets. The leaves look thick and pulpy, different shades of green, with some species showing white flecks on their upper and lower stem surfaces. The margin of the leaf is serrated and has short and small thorns. The flowers are produced from June to September on a spike up to $120 \mathrm{~cm}$, and each yellow tubular corolla flowers are droopy. Healthy and intact plants were collected with equal in length of $24 \mathrm{~cm}$ which is considered to be the optimum plant condition to be examined (Yates, 2002). Prior to the experiment, the juveniles of A. vera were planted in tanks for 3 months to adapt to the experimental environment. 


\section{Experimental process}

Aloe vera was selected for this study because it is not part of the food chain of humans or animals, it can grow in dry arid climates and it is naturally occurring in Saudi Arabia. The growing juveniles of $A$. vera were irrigated with a solution containing inorganic compounds of heavy metals. Aqueous solutions of $15 \mathrm{~g} / \mathrm{l}$ were prepared from the soluble form of each heavy metal. The polluted solution was prepared according to O'Connell et al. (2008). Consequently, the juveniles were irrigated once a month with one liter of clean water in each experimental tank.

The samples were taken from one tank at a time 4 times on a trimester basis. Leaves area was calculated for all samples. Shoots and roots were weighed before air drying. Root and shoot samples were dried in the air than dried in an oven at $60{ }^{\circ} \mathrm{C}$ for two days. Mixed acid digestion procedure was used for preparing the extracts of plant materials. $\mathrm{HClO}_{4}(60 \%)$, concentrated $\mathrm{HNO}_{3}$ and $\mathrm{H}_{2} \mathrm{SO}_{4}$ were mixed in 1:3:1 ratio by volumes. $5 \mathrm{ml}$ was used for the digestion of $0.2 \mathrm{~g}$ of fine powdered dry root and shoot. After digestion on a hot plate is completed as indicated white fumes developed and the solutions became colorless, the volume was completed to $50 \mathrm{ml}$ with distilled water (Allen, 1989; Wade et al., 1984). Experimental design and experimental process are illustrated in Figure 1.

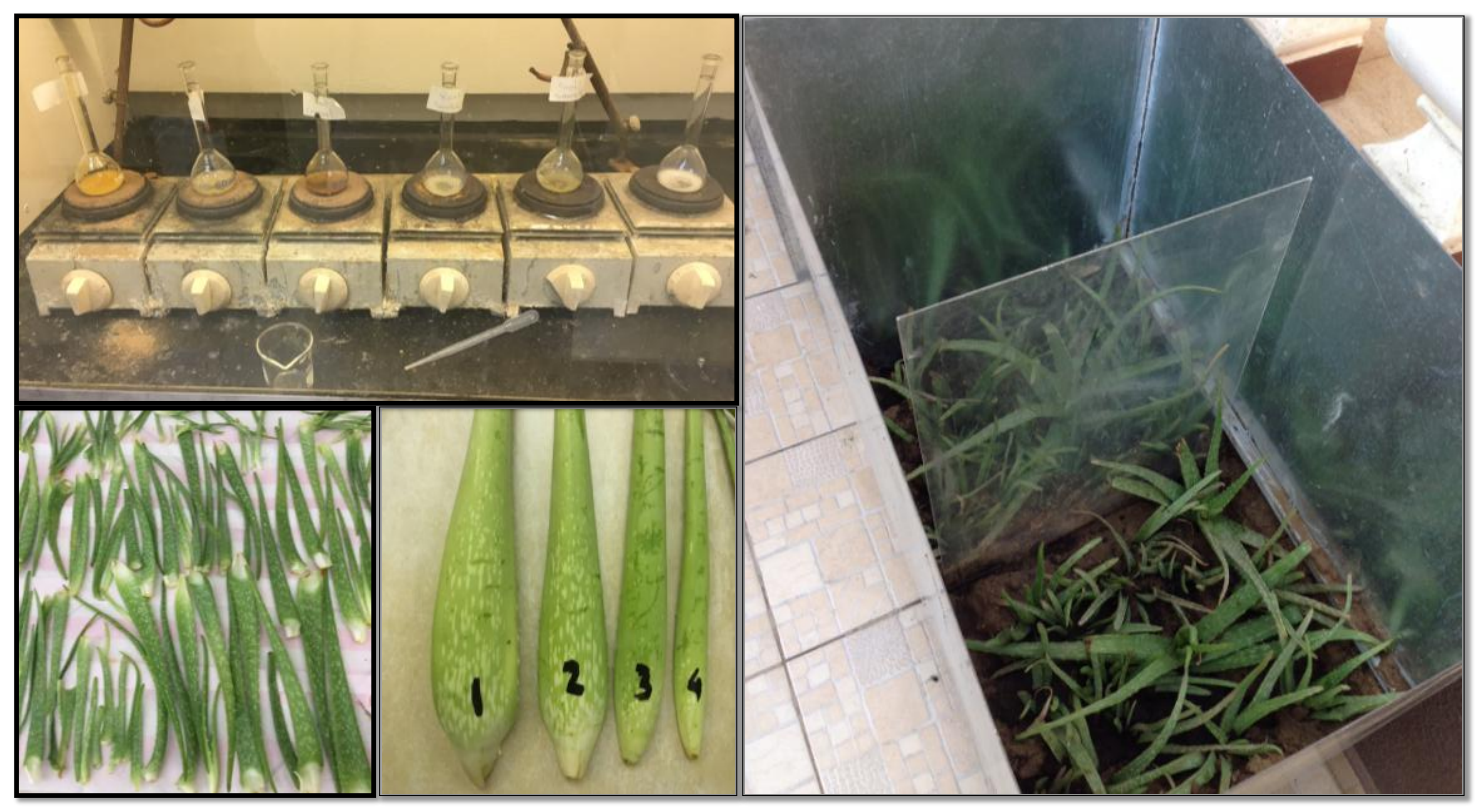

Figure 1. Experimental design and experimental process

\section{MTF and TF calculation}

Metal Transfer Factor (MTF) and Translocation Factor (TF) were calculated from the sample's analysis' data. The calculations of using heavy metal concentration in the extracts of samples were carried out according to the following formulae (Cluis, 2004; Barman et al., 2000; Gupta et al., 2008):

$$
M T F=\frac{\text { metal concentration in plant }}{\text { metal concentration in soil }}
$$




$$
T F=\frac{\text { metal concentration in shoot }}{\text { metal concentration } \text { in root }}
$$

\section{Heavy metals analysis}

$20 \mathrm{~g}$ of plant materials were dried in the air than dried in the oven at $100{ }^{\circ} \mathrm{C}$ for two days. $5 \mathrm{ml}$ of acids were used for digestion of $0.2 \mathrm{~g}$ of plant material (Krumbein and Pettijohn, 1938). In atomic absorption spectroscopy, a liquid sample is aspirated and mixed as an aerosol with combustible gasses (acetylene and air). The mixture is ignited in a flame of temperature ranging from 2100 to $2800{ }^{\circ} \mathrm{C}$. During combustion, atoms of the element of interest in the sample are reduced to the atomic state. A light beam from a lamp, that cathode is made of the element being determined, is passed through the flame into a monochronometer and detector. Free, unexcited ground state atoms of the element absorb light at characteristic wavelengths; this reduction of the light energy at the analytical wavelength is a measure of the amount of the element in the sample (Lindsay and Norvell, 1978).

\section{Results and discussion}

Different heavy metals absorption by $A$. vera showed a different accumulation behavior along with the experimental time demonstrated in Figure 2. Cd accumulation decreased by the time. The highest accumulation of $\mathrm{Cu}$ was after 6 months but it was dropping off after 9 months. $\mathrm{Cr}, \mathrm{Ni}, \mathrm{Pb}$ and $\mathrm{Hg}$ accumulation increased but it dropped after 9 months. The least heavy metal accumulation was detected in the case of $\mathrm{Hg}$. The highest accumulation was As accumulation but it decreased after 9 months.

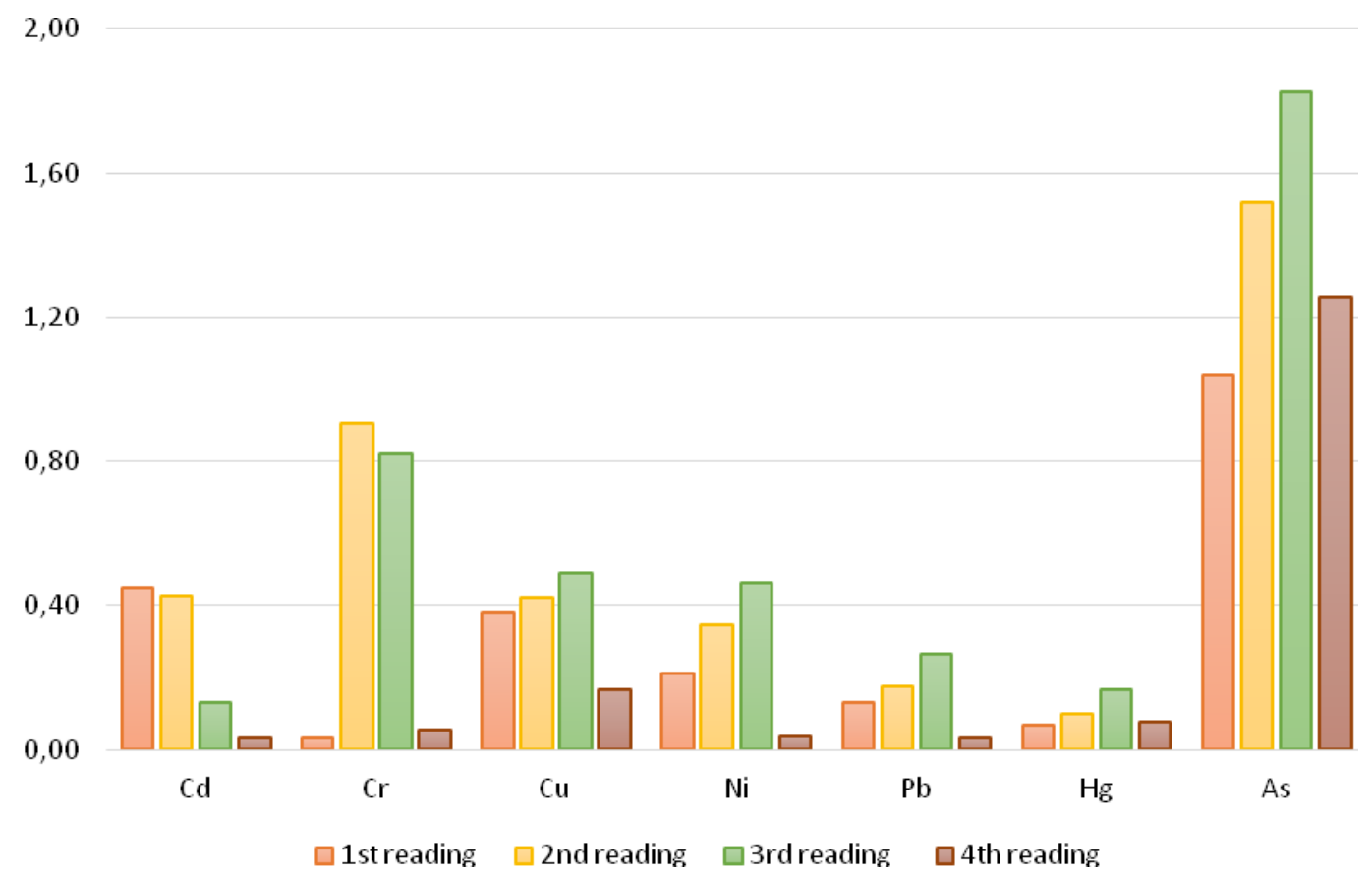

Figure 2. Heavy metal accumulations in the root ( $\mathrm{mg} / \mathrm{l})$ 
Meanwhile, the heavy metal accumulations in the shoot system of $A$. vera showed fewer accumulation rates in general but with less significant behavior in particular with the case of $\mathrm{Cr}$ and $\mathrm{Cu}$ heavy metal accumulation (Fig. 3). Cd accumulation decreased by the time. The highest accumulation of $\mathrm{Cr}$ was after 3 months but it was retreating after that and continued decreasing till the end of the experimental period. $\mathrm{Cu}, \mathrm{Ni}, \mathrm{Pb}$, and $\mathrm{Hg}$ accumulation increased by the time. The least accumulation was detected in the case of $\mathrm{Hg}$. The highest accumulation was As accumulation but it decreased after 9 months.

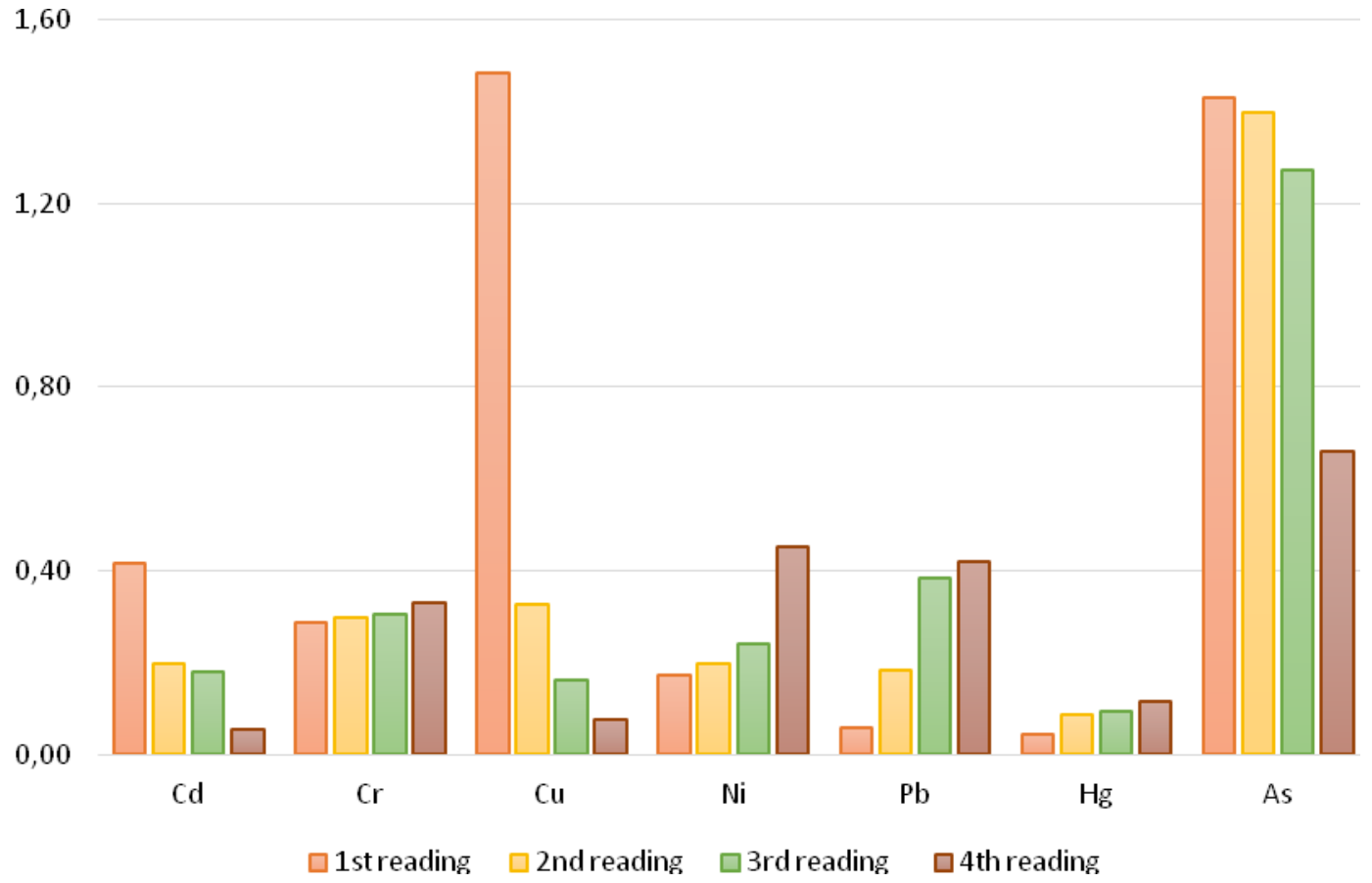

Figure 3. Heavy metal accumulations in the shoot ( $\mathrm{mg} / \mathrm{l})$

Heavy metal accumulations in both roots and shoots are demonstrated in Figure 4. $\mathrm{Cd}$ accumulation decreased over time. The least accumulation was $\mathrm{Hg}$ accumulation. The highest accumulation was As accumulation but it decreased after 9 months. As, $\mathrm{Cu}$, $\mathrm{Ni}, \mathrm{Pb}$ and $\mathrm{Hg}$ accumulation decreased after 9 months. The concentrations of all heavy metals decreased after 9 months.

The plants for phytoremediation should be rather indigenous to the zones where the contaminants are found, as they have developed adaptation and survival strategies suitable to the hard climate in arid and semiarid areas (Piha et al., 1995). Environmental concerns about the use of exotic species and their threat to the indigenous plant communities are of great importance.

For phytoremediation practices, attention should be given to the use of nonpalatable species before efforts are made to grow these plants. This should contain discussions with concerned regulatory agencies and common organizations about the suitability of the plant species as well. However, non-native species may be an acceptable option provided the climatic conditions are the same and the introduced species do not build a new ecological risk (Radwan et al., 1998). 
1,6

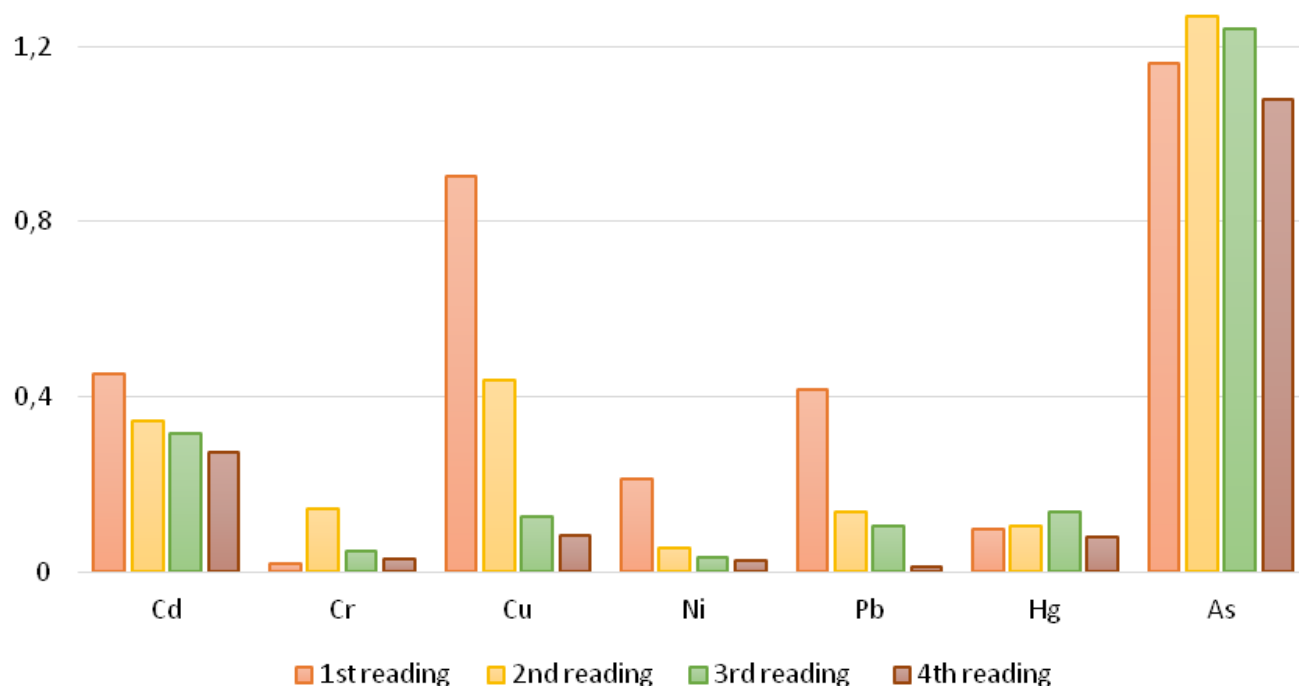

Figure 4. Heavy metal accumulations in Aloe vera ( $\mathrm{mg} / \mathrm{l})$.

The allocation of heavy metals in plant tissues is demonstrated in Figure $5 a-g$. The concentration of $\mathrm{Cu}$ and $\mathrm{Pb}$ are more in shoot than in root. The concentration of $\mathrm{Cd}, \mathrm{Cr}$, $\mathrm{Hg}$ and $\mathrm{As}$ are more in shoot than in root. The concentration of $\mathrm{Ni}$ in root and in the shoot is equal.

The biological effects of heavy metals in plants depend on many ecological factors: the absorptions in the environment, biotic and abiotic factors, exposure time, plant growth, uptake techniques, the affinity of heavy metals for the uptake sites and metals speciation (Mazej and Germ, 2009). Although phytoremediation of contaminated sites in arid and semiarid areas has been attempted by many organizations, the remediation technologies are not properly documented and appear in published literature occasionally. In this study, the current information on phytoremediation for organic and inorganic contaminants in arid and semiarid areas, as well as the potential problems that have an impact on the longstanding practice, are investigated.

$\mathrm{Cd}$

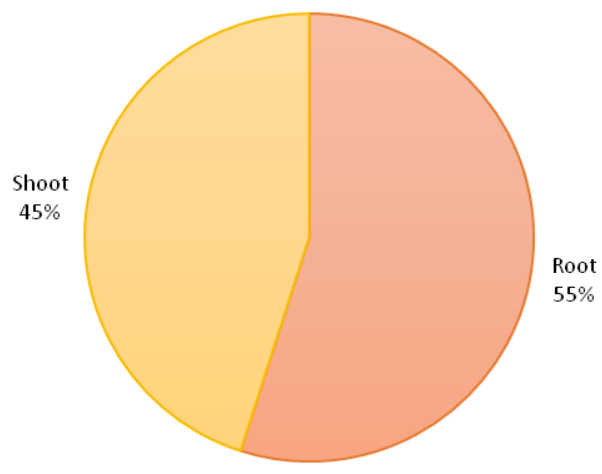

$\square$ Root $\square$ Shoo
$\mathrm{Cr}$

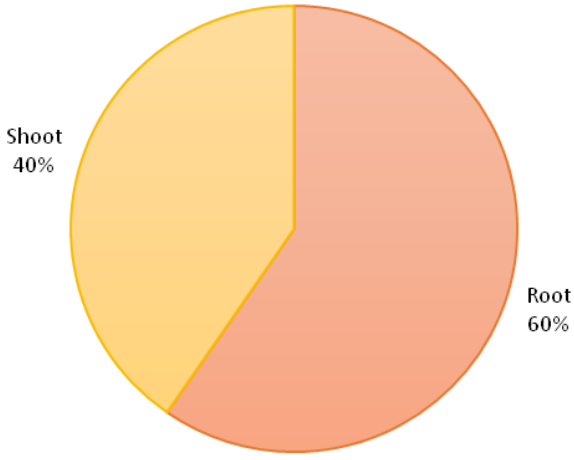

$\square$ Root $\square$ Shoot 
a

$\mathrm{Cu}$

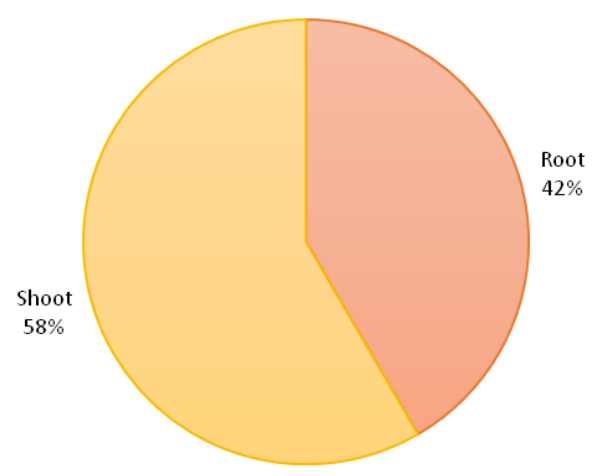

$\square$ Root $\square$ Shoot

c

$\mathrm{Pb}$

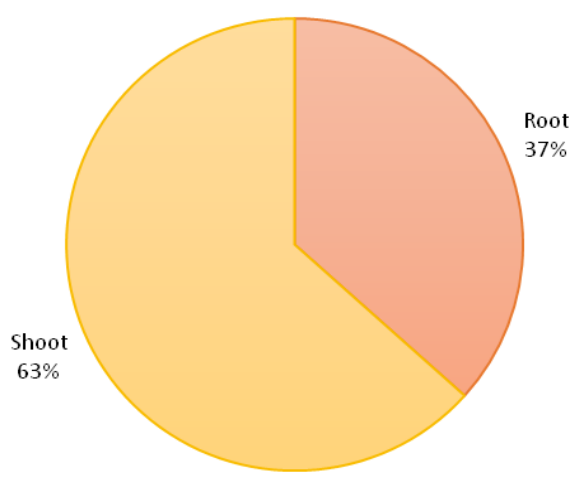

$\square$ Root $\square$ Shoot b

$\mathrm{Ni}$

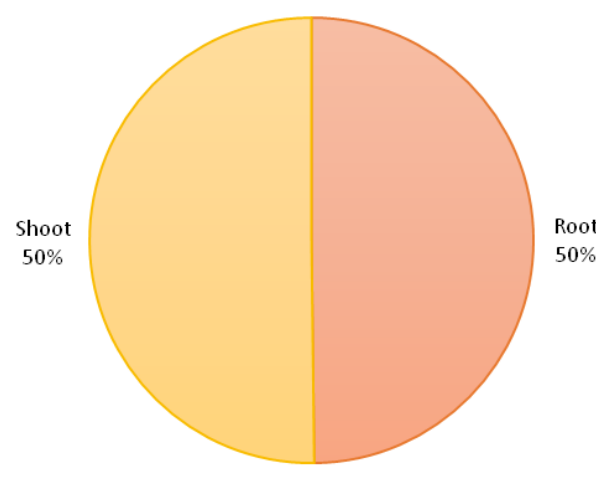

$\square$ Root $\square$ Shoot

d

$\mathrm{Hg}$

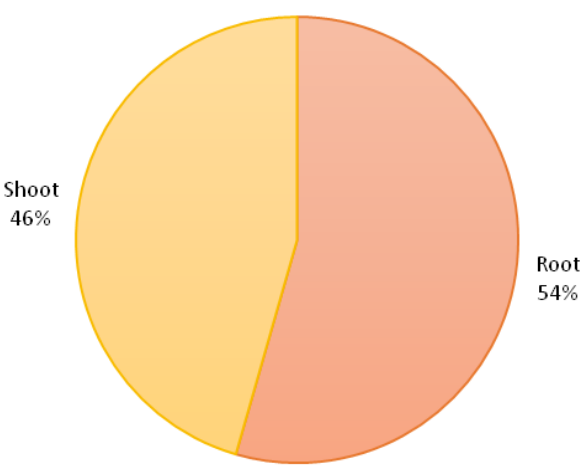

$\square$ Root $\square$ Shoot

f

As

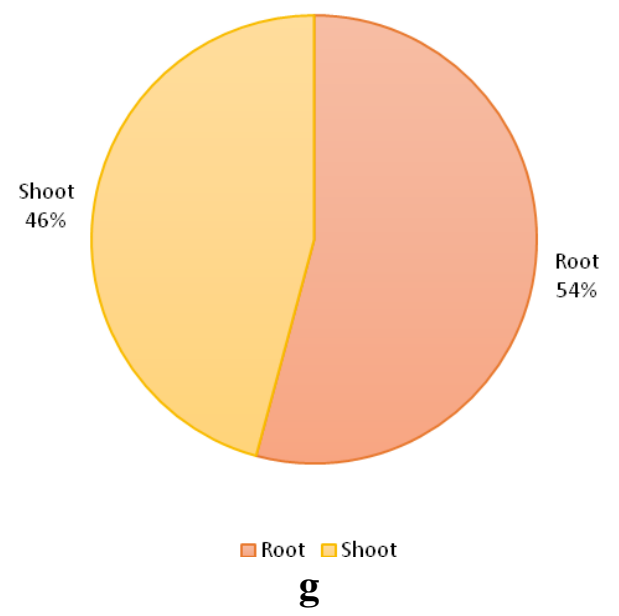

Figure 5. a. Cadmium accumulation. b. Chromium accumulation. $\boldsymbol{c}$. Copper accumulation. $\boldsymbol{d}$. Nickel accumulation. e. Lead accumulation. f. Mercury accumulation. g. Arsenic accumulation 
According to Deng and Wong (2004), Aloe vera can be considered to have a normal accumulation ability according to its Translocation Factor mentioned in Table 1. Different plant species have different TF values based on their affinity to accumulate heavy metals in plant tissues. According to the accumulation ability, phytoremediation plants are categorized into three groups. The first group involves plants with high accumulation ability, like Typha angustifolia and Leersia hexandra. The second group involves plants with normal accumulation ability, like Acorus calamus and Eleocharis valleculosa. The third group involves plants with low accumulation ability, like Neyraudia reynaudiana and Phragmites australis (Deng et al., 2004).

$\mathrm{TF}$ and MTF values are demonstrated in Table $1 . \mathrm{Cu}, \mathrm{Ni}$ and $\mathrm{Pb}$ concentrations are higher in shoot than in root. $\mathrm{Cd}, \mathrm{Cr}, \mathrm{Hg}$ and As concentrations are higher in root than in shoot. A. vera has a high ability to As accumulation, a normal ability to the accumulation of $\mathrm{Cd}, \mathrm{Cr}, \mathrm{Cu}, \mathrm{Ni}$ and $\mathrm{Pb}$, and low abilities to accumulate $\mathrm{Hg}$ (Fig. 6).

Table 1. Translocation factor and metal transfer factor

\begin{tabular}{c|c|c}
\hline & TF & MTF \\
\hline $\mathrm{Cd}$ & 0.820116 & 2.21934 \\
$\mathrm{Cr}$ & 0.676804 & 2.477533 \\
$\mathrm{Cu}$ & 1.402193 & 1.713169 \\
$\mathrm{Ni}$ & 1.00759 & 1.992467 \\
$\mathrm{~Pb}$ & 1.728856 & 1.578417 \\
$\mathrm{Hg}$ & 0.835766 & 2.196508 \\
$\mathrm{As}$ & 0.844858 & 2.183631 \\
\hline
\end{tabular}

$\mathrm{TF}$ of $\mathrm{Cd}, \mathrm{Cr}, \mathrm{Hg}$ and $\mathrm{As}<1$

$\mathrm{TF}$ of $\mathrm{Cu}, \mathrm{Ni}$ and $\mathrm{Pb} \geq 1$

MTF of $\mathrm{Cd}, \mathrm{Cr}, \mathrm{Hg}$ and $\mathrm{As}>2$

MTF of $\mathrm{Cu}, \mathrm{Ni}$ and $\mathrm{Pb}<2$

12

9

6
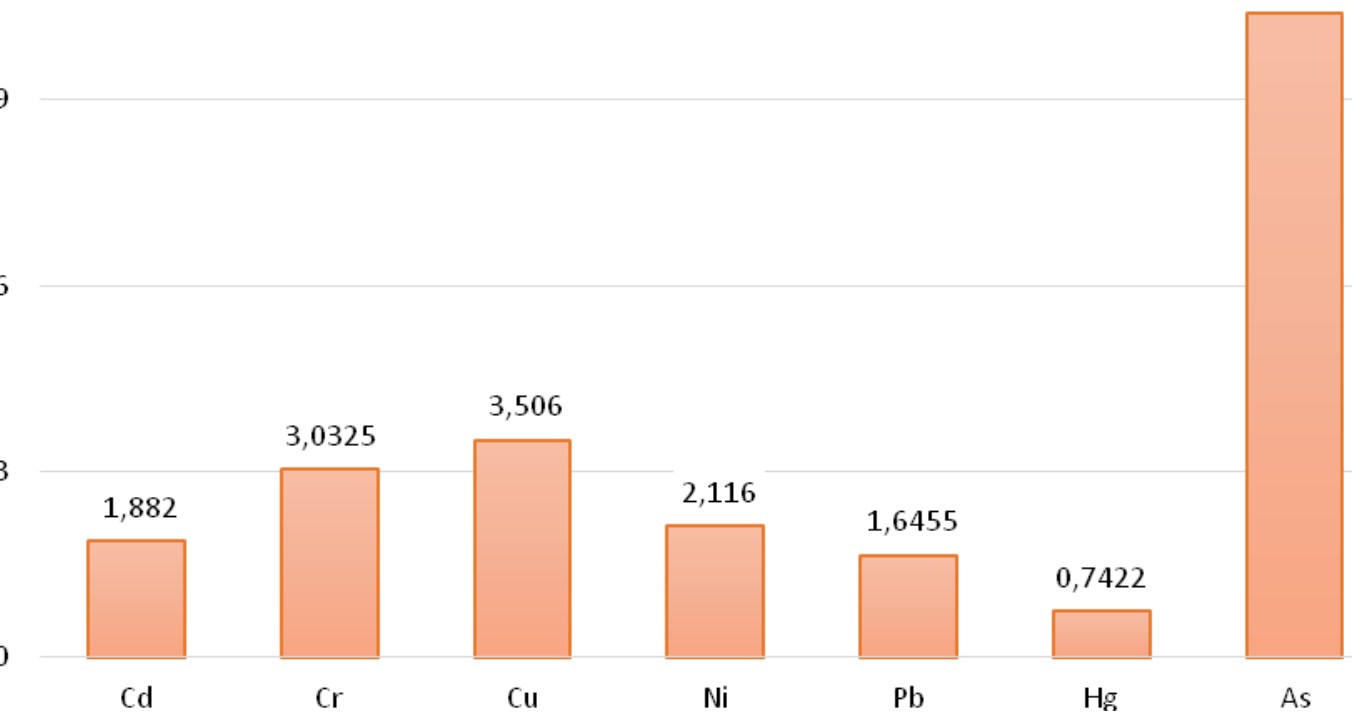
3,506

$\mathrm{Cu}$

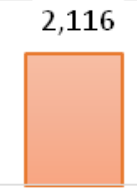

$\mathrm{Ni}$

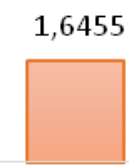

$\mathrm{Pb}$

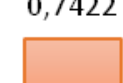

$\mathrm{Hg}$
As

Figure 6. Total heavy metal accumulation $(\mathrm{mg} / \mathrm{l}) /$ year 
In plants, succulence is defined as the presence of thickened tissues in plant organs that the primary function is water-storage and, consequently, drought avoidance (Gibson, 1982; Gibson and Nobel, 1990; Willert, 1992). Because they store water, organs with succulent tissues tend to have a large volume to surface area ratios compared with non-succulent organs in the same plant (Gibson and Nobel, 1990; Rowley, 1987). Such increases in volume result in surface areas with relatively large cross-sectional areas, which leads to greater resistance of bending stresses (Niklas, 1992).

Phytoremediation can be used along with other cleanup techniques. (Padmavathiamma et al., 2014). In general, the use of phytoremediation is confined to sites with low to medium contaminant concentrations, and contamination in the top profile of soils, where phytotoxicity does not occur and the root of the plant can readily access the contaminants (Pivetz, 2001).

\section{Conclusion}

This study showed that the Aloe vera has the abilities to be a phytoremediators to heavy metals from contaminated soil polluted with metals such as (As, $\mathrm{Cd}, \mathrm{Cr}, \mathrm{Cu}, \mathrm{Pb}$, $\mathrm{Hg}$, and $\mathrm{Ni}$ ) due to the great reduction of these metals in the contaminated soils which demonstrates a significant level of affinity to these metals. The results confirm that the cultivation of A. vera is favorable in soils contaminated with Arsenic (As). Moreover, the optimum lifespan of $A$. vera is nine months after its plantation before its affinity to accumulate heavy metals declines. However, A. vera is not recommended for soil polluted with Mercury $(\mathrm{Hg})$. Soil nutrients and soil moisture content among other climatic factors shall be considered in future utilization of Aloe vera in phytoremediation. Further investigation needs to be directed towards using A. vera under several drought conditions instead of regular irrigation to compare the accumulation ability of $A$. vera in different irrigation schedules.

Acknowledgements. This project was funded by the Deanship of Scientific Research (DSR), King Abdulaziz University, Jeddah, under grant no. 184-155-1439-G. The authors, therefore, acknowledge with thanks to DSR's technical and financial support.

\section{REFERENCES}

[1] Ali, H., Khan, E., Sajad, M. A. (2013): Phytoremediation of heavy metals - concepts and applications. - Chemosphere 91: 869-881.

[2] Allen, E. B. (1989): The restoration of disturbed arid landscapes with special reference to mycorrhizal fungi. - Journal of Arid Environments 17: 279-286.

[3] Barman, S., Sahu, R., Bhargava, S., Chaterjee, C. (2000): Distribution of heavy metals in wheat, mustard, and weed grown in field irrigated with industrial effluents. - Bulletin of Environmental Contamination and Toxicology 64: 489-496.

[4] Chakravarty, P., Sarma, N. S., Sarma, H. (2010): Biosorption of cadmium (II) from aqueous solution using heartwood powder of Areca catechu. - Chemical Engineering Journal 162: 949-955.

[5] Cluis, C. (2004): Junk-greedy greens: phytoremediation as a new option for soil decontamination. - BioTeach Journal 2: 1-67. 
[6] Deng, H., Ye, Z., Wong, M. (2004): Accumulation of lead, zinc, copper and cadmium by 12 wetland plant species thriving in metal-contaminated sites in China. - Environmental Pollution 132: 29-40.

[7] Dunbabin, J. S., Bowmer, K. H. (1992): Potential use of constructed wetlands for treatment of industrial wastewaters containing metals. - Science of the Total Environment 111: 151-168.

[8] Elhag, M., Bahrawi, J. (2014a): Cloud coverage disruption for groundwater recharge improvement using remote sensing techniques in Asir Region Saudi Arabia. - Life Science Journal 11: 192-200.

[9] Elhag, M., Bahrawi, J. A. (2014b): Conservational use of remote sensing techniques for a novel rainwater harvesting in arid environment. - Environmental Earth Sciences 72: 4995-5005.

[10] Elhag, M., Bahrawi, J. A. (2016): Consideration of geo-statistical analysis in soil pollution assessment caused by leachate breakout in the municipality of Thermi, Greece. - Desalination and Water Treatment 57: 27879-27889.

[11] Elhag, M., Hegazy, A. K., Alatar, A. A., Faisal, M., El-Bana, M., Bahrawi, J. A., AlGhamdi, A. A. M. (2015): Population demography and global sensitivity analysis of Avicennia marina on the eastern and western coasts of Saudi Arabia. - Koedoe 57: 1-9.

[12] Elhag, M., Bahrawi, J. A., Galal, H. K., Aldhebiani, A., Al-Ghamdi, A. A. (2017a): Stream network pollution by olive oil wastewater risk assessment in Crete, Greece. Environmental Earth Sciences 76: 278.

[13] Elhag, M., Galal, H. K., Alsubaie, H. (2017b): Understanding of morphometric features for adequate water resource management in arid environments. - Geoscientific Instrumentation, Methods and Data Systems 6: 293.

[14] Garbisu, C., Alkorta, I. (2003): Basic concepts on heavy metal soil bioremediation. ejmp \& ep (European Journal of Mineral Processing and Environmental Protection) 3: $58-66$.

[15] Gibson, A. C. (1982): Phylogenetic Relationships of Pachycereeae. - In: Barker, J. S. F., Starmer, W. T. (eds.) Ecological Genetics and Evolution: The Cactus-Yeast-Drosophila Model System. Academic Press, New York.

[16] Gibson, A. C., Nobel, P. S. (1990): The Cactus Primer. - Harvard University Press, Cambridge, MA.

[17] Grzebisz, W., Ciesla, L., Diatta, J. (2001): Spatial distribution of copper in arable soils and in non-consumable crops (flax, oil-seed rape) cultivated near a copper smelter. Polish Journal of Environmental Studies 10: 269-274.

[18] Gupta, S., Nayek, S., Saha, R., Satpati, S. (2008): Assessment of heavy metal accumulation in macrophyte, agricultural soil, and crop plants adjacent to discharge zone of sponge iron factory. - Environmental Geology 55: 731-739.

[19] Hughes, J. B., Shanks, J., Vanderford, M., Lauritzen, J., Bhadra, R. (1996): Transformation of TNT by aquatic plants and plant tissue cultures. - Environmental Science \& Technology 31: 266-271.

[20] Krumbein, W. C., Pettijohn, F. J. (1938): Manual of Sedimentary Petrography. Appleton Century Crofts, New York.

[21] Lindsay, W. L., Norvell, W. A. (1978): Development of a DTPA soil test for zinc, iron, manganese, and copper. - Soil Science Society of America Journal 42: 421-428.

[22] Mazej, Z., Germ, M. (2009): Trace element accumulation and distribution in four aquatic macrophytes. - Chemosphere 74: 642-647.

[23] Newton, L. (2001): Sansevieria. - In: Eggli, U. (ed.) Illustrated Handbook of Succulent Plants: Monocotyledons. Springer, New York, pp. 261-272.

[24] Niklas, K. J. (1992): Petiole mechanics, light interception by lamina, and "economy in design". - Oecologia 90: 518-526. 
[25] O'connell, D. W., Birkinshaw, C., O'dwyer, T. F. (2008): Heavy metal adsorbents prepared from the modification of cellulose: A review. - Bioresource Technology 99: 6709-6724.

[26] Padmavathiamma, P. K., Li, L. Y. (2007): Phytoremediation technology: hyperaccumulation metals in plants. - Water, Air, and Soil Pollution 184: 105-126.

[27] Padmavathiamma, P. K., Ahmed, M., Rahman, H. A. (2014): Phytoremediation-A sustainable approach for contaminant remediation in arid and semi-arid regions-a review. - Emirates Journal of Food and Agriculture 26: 757.

[28] Parrish, Z. D., Banks, M. K., Schwab, A. P. (2005): Effect of root death and decay on dissipation of polycyclic aromatic hydrocarbons in the rhizosphere of yellow sweet clover and tall fescue. - Journal of Environmental Quality 34: 207-216.

[29] Peer, W. A., Baxter, I. R., Richards, E. L., Freeman, J. L., Murphy, A. S. (2005): Phytoremediation and Hyperaccumulator Plants. - In: Tamás, M. J., Martinoia, E. (eds.) Molecular Biology of Metal Homeostasis and Detoxification. Springer, Berlin.

[30] Piha, M., Vallack, H., Reeler, B., Michael, N. (1995): A low input approach to vegetation establishment on mine and coal ash wastes in semi-arid regions. I. Tin mine tailings in Zimbabwe. - Journal of Applied Ecology: 372-381.

[31] Pivetz, B. E. (2001): Ground Water Issue: Phytoremediation of Contaminated Soil and Ground Water at Hazardous Waste Sites. - National Risk Management Research Lab, Ada OK.

[32] Prasad, V. M. N., Freitas, D. O. H. M. (2003): Metal hyperaccumulation in plants: biodiversity prospecting for phytoremediation technology. - Electronic Journal of Biotechnology 6: 285-321.

[33] Radwan, S., Al-Awadhi, H., Sorkhoh, N., El-Nemr, I. (1998): Rhizospheric hydrocarbonutilizing microorganisms as potential contributors to phytoremediation for the oil Kuwaiti desert. - Microbiological Research 153: 247-251.

[34] Reeves, R. D., Baker, A. J. M. (2000): Metal-Accumulating Plants. - In: Raskin, I., Ensley, B. D. (eds.) Phytoremediation of Toxic Metals: Using Plants to Clean Up the Environment. Wiley, New York.

[35] Rashed, M., Niyazi, B. (2017): Environmental impact assessment of the former Al-Musk Lake wastewater dumpsite using electromagnetic induction technique. - Earth Systems and Environment 1: 1-10.

[36] Rowley, G. D. (1987): The Duchess of Beaufort's succulent plants. - Bradleya 5: 1-16.

[37] Şen, Z., Al-Harithy, S., As-Sefry, S., Almazroui, M. (2017): Aridity and risk calculations in Saudi Arabian wadis: Wadi Fatimah case. - Earth Systems and Environment, 1: 26-37.

[38] Schwab, A., Banks, M. (1993): Biologically Mediated Dissipation of Polyaromatic Hydrocarbons in the Root Zone. - In: Anderson, T. A., Coates, J. R. (eds.) Bioremediation through Rhizosphere Technology. ACS Publications, Washington.

[39] Thangavel, P., Subbhuraam, C. (2004): Phytoextraction: role of hyperaccumulators in metal contaminated soils. - Proceedings-Indian National Science Academy Part B, 70: 109-130.

[40] Tiller, K. (1992): Urban soil contamination in Australia. - Soil Research 30: 937-957.

[41] Wade, T., Brooks, J., Kennicutt, L., Mcdonald, J., Sericano, J., Jackson, T. (1984): GERG trace organics contaminant analytical techniques. - Sampling and Analytical Methods of the National Status and Trends Program, National Benthic Surveillance and Mussel Watch Projects 1992: 121-139.

[42] Walker, C. (2005): A tale of two Arabian aloes. - British Cactus \& Succulent Journal 23: 175-179.

[43] Willert, D. J. V. (1992): Life Strategies of Succulents in Deserts: With Special Reference to the Namib Desert. - Cambridge University Press, Cambridge.

[44] Williams, V., Twine, S. (1960): Flame photometric method for sodium, potassium and calcium. - Modern Methods of Plant Analysis 5: 3-5. 
[45] Wong, J. (1996): Heavy metal contents in vegetables and market garden soils in Hong Kong. - Environmental Technology 17: 407-414.

[46] Yates, A. (2002): Yates Garden Guide. - Harper Collins, Australia. 